\title{
NPY Gene
}

National Cancer Institute

\section{Source}

National Cancer Institute. NPY Gene. NCI Thesaurus. Code C39647.

This gene plays a role in the cellular proliferation of neuronal precursor cells. 